University of Northern lowa

UNI ScholarWorks

$2-2013$

\title{
Speaking politely, kindly, and beautifully: Ideologies of politeness in Japanese business etiquette training
}

Cynthia Dickel Dunn

University of Northern lowa

Let us know how access to this document benefits you

Copyright @2013 De Gruyter. The copyright holder has granted permission for posting.

Follow this and additional works at: https://scholarworks.uni.edu/sac_facpub

Part of the Anthropology Commons, Criminology and Criminal Justice Commons, and the Sociology Commons

\section{Recommended Citation}

Dunn, Cynthia Dickel, "Speaking politely, kindly, and beautifully: Ideologies of politeness in Japanese business etiquette training" (2013). Faculty Publications. 1.

https://scholarworks.uni.edu/sac_facpub/1

This Article is brought to you for free and open access by the Faculty Work at UNI ScholarWorks. It has been accepted for inclusion in Faculty Publications by an authorized administrator of UNI ScholarWorks. For more information, please contact scholarworks@uni.edu. 


\section{Cynthia Dickel Dunn}

\section{Speaking politely, kindly, and beautifully: Ideologies of politeness in Japanese business etiquette training}

Abstract: In recent years, politeness theory has increasingly focused on speakers' own conceptualizations of polite behavior, viewing politeness concepts as a type of language ideology. This article examines the construction of Japanese politeness concepts in the business etiquette training provided for new employees in Japanese companies. Drawing on participant-observation of business etiquette seminars offered by five training companies, it analyzes how employees are taught to show deference through appropriate honorific use, to speak in ways which are seen as kind or considerate, and to speak and move in ways the instructors define as 'beautiful.' The analysis demonstrates how etiquette training conflates displays of deference, kindness, and demeanor, training new employees in an interactional presentation of self designed to promote a positive corporate image. The analysis of politeness as language ideology reveals how local constructions of politeness can serve larger strategic ends, in this case those of corporate image-making.

Keywords: politeness theory, language ideology, workplace communication, business etiquette, Japanese

Cynthia Dickel Dunn: Dept. of Sociology, Anthropology \& Criminology, University of Northern lowa, Cedar Falls, IA 50614-0513 U.S.A, e-mail: Cyndi.Dunn@uni.edu

\section{Introduction}

In Japan, the transition from being students to becoming full-time workers and mature, adult shakaijin 'members of society,' involves major shifts in self-presentation and language use. Despite the fact that most college students have engaged in part-time work, they are frequently seen as ill-prepared for the behaviors and language use that are expected in the business world. Consequently, many companies provide recently hired graduates with training in polite language use and other aspects of business etiquette as part of their new employee orientation. Although some companies provide this training them- 
selves, there are also burgeoning numbers of firms specializing in workforce development training which provide one or two-day seminars in bijinesu manaa 'business manners' for employees of other companies. Such courses cover everything from appropriate honorific use to how to bow and present one's business card. This article analyzes the concepts of 'politeness' that are manifest in such training.

In recent years, politeness has come to be seen less as an objective property of decontextualized linguistic forms than as an evaluative interpretation of situated behaviors (Eelen 2001; Mills 2003; Locher \& Watts 2005; Pizziconi 2006). This has led to greater attention to how native speakers themselves conceptualize (im)polite behavior. Watts et al. (1992) distinguish between Politeness1, characterized as how politeness is 'perceived and talked about by members of sociocultural groups' and Politeness2, conceived as 'theoretical constructs.' Building on this distinction, Eelen (2001) argues for greater attention to Politeness1, which he further subdivides into three categories: expressive politeness (politeness encoded in speech), classificatory politeness (people's evaluative judgments of other people's speech as (im)polite), and metapragmatic politeness (talk about politeness).

Of course, there is frequently a disjuncture between people's expressive practices and the metapragmatic discourses which seek to regiment them. This can be understood in terms of an additional argument made by Eelen, namely that classificatory and metapragmatic Politeness1 are always both evaluative and socially interested. That is, they are not neutral representations of practices (as would be the goal in Politeness2), but rather evaluations of practice by socially positioned and interested actors. Drawing on Bourdieu, Eelen notes that representations of reality often function as struggles over reality insofar as representations may also aim to realize the very model that they represent. Rather than objectifying such representations, social science must recognize and include the struggle over representations as part of its own model of reality.

Recent developments in politeness theory thus invite us to view politeness as a form of language ideology, defined by Irvine as 'the cultural system of ideas about social and linguistic relationships together with their loading of moral and political interests' (1989: 255). This loading of political and moral interests is readily apparent in Japanese public discourse regarding proper etiquette, language use, and honorifics. Newspapers frequently carry commentary or letters to the editor in which writers debate appropriate honorific use (Okamoto 1999) or criticize young women's speech as lacking politeness and femininity (Okamoto 1995; Inoue 2006: 174-182). The Japanese government has long been concerned with standardizing honorific use (Wetzel 2004) and recently issued a new set of guidelines for correct usage (Kokugo Shingikai [Japan 
National Language Council] 2000). There is also a voluminous popular 'how-to' literature covering all aspects of linguistic etiquette from proper honorific use, to telephone speech, to job interviews, to wedding speeches (Wetzel 2004). Such guides promise to assuage the anxiety which is created by prescriptive discourses of correctness, including those of the self-help industry itself.

The training in business etiquette given to new employees entering Japanese companies is one instance of this larger aparatus of metapragmatic regimentation. In corporate 'business manners' training, instructors engage in metapragmatic discourse with the aim of controlling both the expressive politeness and the classificatory politeness behaviors of the students. These come together in metapragmatic statements of classificatory politeness - categorizing some actions as (im)polite in order to shape both the actions and the judgments of the students. As with the other prescriptive discourses described above, manner training defines standards of polite behavior in the very process of inculcating them, allowing us to see processes of the cultural (re)construction of Politeness1 in action.

This article examines the concepts of politeness which are manifest in Japanese business manners training and how they are used to shape employees' presentation of an appropriate corporate image. It begins with a brief survey of the recent literature on Japanese conceptualizations of 'politeness.' This is followed by an ethnographic analysis of how politeness is presented in business manners courses. The analysis is based on participant-observation, field notes, and audio recordings of manners courses presented by five different training companies. Drawing on the instructors' metalinguistic discourse and critiques of students' behavior, I elucidate three areas which are central to the mode of self-presentation emphasized in these courses: speaking politely, kindly, and beautifully. The language ideologies presented in the business manners course fuse concepts of deference, consideration for others, and presentation of an appropriate demeanor in ways which serve the larger project of presenting a positive corporate image.

\section{The semantics of teinei}

A number of scholars have carried out semantic analyses of the concept of teinei in Japanese, frequently in contrast to politeness in various national dialects of English (Ide et al. 1992; Obana \& Tomoda 1994; Haugh 2004; Pizziconi 2007). These studies use various forms of elicited data such as questionnaires and interviews to compare Japanese concepts of teinei with English-language concepts of polite and to map out the relationship of teinei to other similar con- 
Ide et al. 1992

Obana \& Tomoda Haugh 2004

Pizziconi 2007 1994

\begin{tabular}{|c|c|c|c|}
\hline $\begin{array}{l}\text { Words associated with } \\
\text { teinei }\end{array}$ & $\begin{array}{l}\text { Words associated } \\
\text { with teinei, reigi } \\
\text { tadashii }\end{array}$ & $\begin{array}{l}\text { Words associated } \\
\text { with teinei, reigi } \\
\text { tadashii }\end{array}$ & $\begin{array}{l}\text { Words associated with } \\
\text { teinei, keigo }\end{array}$ \\
\hline $\begin{array}{l}\text { Ratings of behavior } \\
\text { scenarios }\end{array}$ & Interviews & Dictionary definitions & $\begin{array}{l}\text { Free association and } \\
\text { lexical mapping }\end{array}$ \\
\hline keii no aru 'respectful' & $\begin{array}{l}\text { keigo 'honorifics' } \\
\text { jooge kankei } \\
\text { 'vertical relations' }\end{array}$ & $\begin{array}{l}\text { keii 'respect' } \\
\text { sahoo 'etiquette' }\end{array}$ & $\begin{array}{l}\text { reigi tadashi } \\
\text { 'well-mannered' } \\
\text { joohin 'refined' }\end{array}$ \\
\hline $\begin{array}{l}\text { kanji yoi 'pleasant' } \\
\text { tekisetsu 'appropriate' } \\
\text { omoiyari no aru } \\
\text { 'considerate' }\end{array}$ & tachiba 'position' & $\begin{array}{l}\text { shinsetsu kind' } \\
\text { teatsui 'warm' } \\
\text { nengoro 'courteous' }\end{array}$ & $\begin{array}{l}\text { shinsetsu 'kind' } \\
\text { seijitsu 'sincere' } \\
\text { omoiyari no aru } \\
\text { 'considerate' }\end{array}$ \\
\hline & $\begin{array}{l}\text { wakimaeru } \\
\text { 'discerning' } \\
\text { hikaeme 'discrete' } \\
\text { enryo 'restraint' }\end{array}$ & hikaeme 'modesty' & $\begin{array}{l}\text { wakimaeru } \\
\text { 'discerning' } \\
\text { kenkyo 'modest' } \\
\text { herikudaru 'humble' } \\
\text { enryogachi 'reserved' }\end{array}$ \\
\hline
\end{tabular}

Table 1: Previous studies of words associated with teinei.

cepts. The studies provide semantic analyses of words and concepts associated with the words teinei 'polite,' reigi tadashii 'well-mannered,' and keigo 'honorifics' (see table 1).

Despite somewhat different methodological approaches, a number of common themes are apparent in these studies. The concept of teinei in Japanese is associated with clusters of other concepts including vertical displays of respect (keii 'respect,' keigo 'honorifics' or literally 'respect language,' jooge kankei 'vertical relations'), appropriate modesty or humility (hikaeme 'modesty,' enryo 'restraint,' kenkyo 'modest,' herikudaru 'humble'), and showing kindness or consideration to others (shinsetsu 'kind,' omoyari 'considerate'). In Pizziconi's study (2007), respondents were asked to rate each of the adjectives in terms of how similar or different they perceived it to be from the other nine terms. Semantic mapping revealed two main underlying semantic dimensions. The first of these involves whether the behavior shows an orientation towards the other person versus the speaker's own image. Thus, joohin 'refined,' reigi tadashii 'well-mannered,' and teinei 'polite' have to do with 'the payoff, for an individual, of being polite in interaction' (Pizziconi 2007: 226), whereas the other 
terms emphasize the individual's affective concern for others. The second dimension of contrast distinguishes more direct and affectively involved expressive modes (shinsetsu 'kind,' seijitsu 'sincere,' omoiyari no aru 'considerate') from more reserved and indirect ones (kenkyo 'modest,' herikudaru 'humble,' enryogachi 'reserved').

These studies provide an initial foundation for the analysis of Japanese understandings of 'politeness.' They are, however, based on decontextualized semantic analysis, whether drawn from dictionary definitions (Haugh 2004) or semantic judgments elicited by the researchers (Ide et al. 1992; Pizziconi 2007). Although these studies provide an initial starting point for the analysis of Japanese conceptualizations of teinei behavior, they cannot provide us with an understanding of how speakers deploy these concepts for their own ends in naturally-occurring metapragmatic discourse. Thus, they take us only part way towards Eelen's goal of understanding how local concepts of Politeness1 are used to make evaluative judgments.

\section{Language socialization and language ideologies}

The present study builds on previous research by examining how Japanese understandings of politeness are (re)created in one specific interactional context, namely the business manners training provided to new employees in Japanese companies. Business manners training provides an outstanding context for such an analysis because speakers are engaged in explicit evaluative judgments of politeness for their own ends rather than those of the researcher. Scholars have long looked at language socialization practices as a site for examining how speakers learn cultural values and practices in the process of learning language (Clancy 1986; Schieffelin \& Ochs 1986; Garrett \& Baquedano-Lopez 2002). Language socialization continues across the lifespan as speakers move into new social roles and situations (Dunn 1999). Business manners training offers a window into processes through which young adults are trained to reshape their language use and presentation of self in ways that are considered appropriate for the business world. It thus allows us to examine processes of norm construction in action.

Such socialization into politeness norms involves constructing and promulgating language ideology. Metalinguistic discourses are always partial, interestladen, and contestable (Woolard 1998; Eelen 2001). Thus, the discourses analyzed here should be seen neither as neutral and objective statements about 
social norms, nor as representing concepts of politeness which are uniformly shared across all areas of Japanese society. Rather, the business manners training is valuable precisely for the insight it provides into processes through which concepts of politeness are (re)created and manipulated in the service of larger strategic interests.

Researchers have approached the study of language ideologies from a variety of perspectives, ranging from those who focus primarily on explicit metalinguistic discourse to those who attempt to uncover the ideologies that implicitly underlie linguistic practices (Woolard 1998). Several of the contributors to this special issue take the latter approach, uncovering concepts of politeness which are immanent in Japanese interaction. There is also value in recognizing how situated evaluations of the (im)politeness of utterances are embedded in wider societal discourses of gender, social class, and region (e.g., Cameron 1998; Mills 2003; Shibamoto Smith \& Occhi 2009). Arguably the most interesting approach, however, is one which examines the disjunctures between everyday lived practices and the more explicit discourses which seek to regiment them. That is the project of the present article, which explores the relationship between the linguistic and bodily practices that recent college graduates bring to the workplace and the ideal model into which the business manner training attempts to mold them. I thus focus on Eelen's category of metapragmatic politeness (discourse about politeness) as a way of investigating the discourses through which widely shared understandings of 'politeness' are constructed and promulgated in Japanese society as well as how they may serve certain, in this case corporate, interests.

\section{Data and methodology}

As described above, there are currently numerous companies in Japan specializing in workforce development training which provide one- or two-day seminars in business manners for employees of other companies. The present analysis is based on participant-observation of business manners courses offered by five training companies in the Tokyo area during spring 2008. All but one of the companies were initially identified through a Google search for companies providing business manners training (bijinesu manaa kenshuu). I contacted the companies via email to explain my research and ask permission to attend one of their courses. I made contact with one additional company through a personal introduction. Of the eight companies I contacted, five granted permission to observe or attend one of their seminars. I participated in two of the seminars 
as a student. For the other three courses, I sat in the back of the room and observed and took notes without participating.

Two of the courses were designed specifically for employees of particular companies (a temp agency and a company manufacturing cosmetics and personal hygiene products). The other three were 'open seminars' attended by employees from a variety of different companies. The majority of the students were white-collar, managerial employees although there were a variety of occupations represented including hotel manager, chef, receptionist, clerical staff, wedding coordinator, facilities management, sales, computer engineer, and technical support. Employers included an insurance firm, wedding hall, hotels, a graphic design company, and several small manufacturing firms. All of the students except me were native speakers of Japanese. The size of the classes ranged from five to twenty students. I audio recorded two of the training sessions in their entirety. I also interviewed four instructors and three students from the courses I attended.

Verbatim transcripts of two of the training courses as well as detailed field notes on all five were analyzed following a grounded-theory approach (Charmaz 2001) in which themes and categories are allowed to emerge from the data rather than being determined a priori. This approach is well-suited for explicating participants' own understandings of cultural constructs, particularly when one has a corpus of relatively explicit discourse on the topic. In common with ethnographic methods more generally, it has the value of enabling serendipitous discovery (Omohundro 2008: 70) of concepts, and connections among concepts, that were not anticipated by the researcher. The analysis used Atlas.ti ${ }^{\mathrm{TM}}$, a software program for qualitative data analysis which allows inductive coding of units ranging from words or phrases, through whole paragraphs, up to entire documents. This was an iterative, inductive process of reading and rereading the data, using the program's coding function to mark themes and topics, and then rereading and recoding on finer levels, followed by tracing links and associations among the different codes. The Atlas.ti ${ }^{\mathrm{TM}}$ program allows one to subdivide codes into smaller categories, group them together in 'Families,' trace one code through the data and see which other codes co-occur with it, or request as output all quotations relating to a single code or the intersection of two or more codes. The program does not determine the analysis, but rather aids in marking, organizing, and retrieving concepts without losing their situated context. ${ }^{1}$

1 For an excellent overview of the capabilities of currently available software for qualitative analysis, see Lewins \& Silver (2007). 
Each of the main concepts elucidated here, 'politeness,' 'kindness,' and 'beauty,' is based on this inductive and iterative discovery of concepts in the data. Analysis of the use of specific phrases relied most heavily on the two classes for which I have verbatim transcripts. Detailed field notes from the remaining three classes were used to confirm that the themes that emerged from the analysis were not idiosyncratic to one particular class or instructor.

\section{Overview of the classes}

Although the five courses I attended differed somewhat in their sequencing and presentation, much of the basic content was the same in all of them (see table 2). In addition to language use, the training covered physical appearance, vocal and facial expression, and proper movement. Three of the five courses had a section on personal grooming with check sheets for hair (clean and neat, appropriate length, natural color), clothing (properly ironed, not dirty or torn, appropriate colors and styles), feet (properly polished shoes, no sport socks), and so forth. Students were trained in the use of their voices including enunciation, projection, using a higher than normal pitch when speaking standard greetings, and responding with a loud, prompt Hai! when called on by superiors. Four of the courses included a section on movement with training in how to sit, stand, walk, and hand over objects. All of the courses had a section on bowing which covered both posture and timing such as remaining bent at the correct angle for the correct number of seconds. The courses included training on polite language and honorific use, and there were specific sections on answering the telephone including practice at taking a message, explaining that the person is not currently available, and so forth. Students received instruction in the ritual-

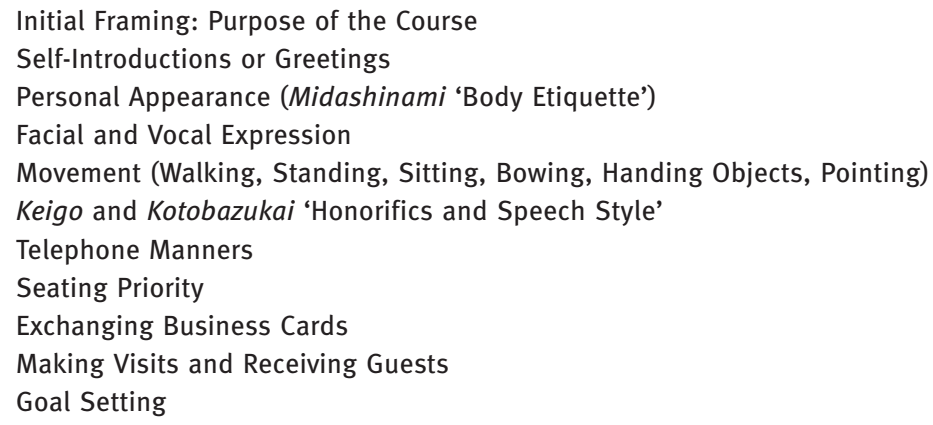

Table 2: Typical contents of Japanese business manner training. 
ized details of how to exchange business cards and how to determine correct seating order at a conference table, in a taxi, and so forth. Following each of these separate sections, groups of students typically engaged in a role play of people from one company visiting another which allowed them to put together all of the different linguistic and non-linguistic components.

Two of the courses made use of video recording to allow students to reflect on their own self-presentation. Students were recorded while performing a oneminute self-introduction or role playing telephone interactions or company visits. The students viewed the videos, and each person was asked to comment on the strengths and weaknesses of his or her performance. They were then critiqued by the instructors, who identified both positive and negative aspects of the students' self-presentation. Such critiques are particularly valuable because they permit us to identify specific verbal and non-verbal behaviors which were viewed by the instructors as problematic or in need of correction. They thus allow us to examine the disjunctures between everyday lived practices of politeness and the more explicit discourses which seek to regiment them.

\section{Ideologies of politeness: Speaking politely, kindly, and beautifully}

Three of the courses I observed began by framing the manners training in terms of the English phrase 'Customer Satisfaction,' abbreviated as 'CS' and translated as kokyaku manzoku. One of the instructors explained the importance of Customer Satisfaction with the following example:

If you think back ten, twenty years depending on your age, there were some restaurants that were delicious and some where the food was not so good. But in recent years, the quality of restaurants has improved to the point where most of them serve good food. So why do you choose one restaurant over another? It's based on the employees and the level of service that they provide. So these days every business absolutely has to be thinking about customer satisfaction if they want to be competitive. (Field notes 3/4/08)

Instructors told the students that they should think of themselves as the representative of their company (kaisha no daihyoo). Having good manners is not simply a matter of creating a positive impression of yourself as an individual, but creates a positive image for the entire company.

In business manners training, inculcating polite behaviors is not an end in itself, but rather occurs as part of a larger project of creating Customer Satisfaction and projecting a positive corporate image. This, in turn, shapes the defini- 
tion of politeness that is constructed in these courses. The following analysis delineates three broad themes that comprise the concept of politeness that is manifest in business manners training courses. First, students are taught to speak in ways that are teinei 'polite,' which chiefly involves training in the use of the more formal or deferential levels of the honorific system. Second, the courses instruct new employees to speak in ways which are yasashii 'kind,' or show consideration towards the addressee. Finally, there is a great deal of concern with speaking in ways which are kirei 'beautiful.' This latter concern, I will argue, is closely connected to the display of an appropriate demeanor as a representative of one's company. Manners training thus fuses concepts of deference and demeanor in the interests of projecting a desirable company image.

\subsection{Teinei: Displaying deference}

A central component of 'politeness' in Japanese involves the indexing of social position through the display of appropriate deference to those of higher social status. Studies of native speaker semantic judgments consistently reveal that being teinei 'polite' is closely associated with the expression of 'respect' (keii) and use of keigo 'honorific language' (Ide et al. 1992; Obana \& Tomoda 1994; Pizziconi 2007). One reason frequently given for the necessity of business manners training is that young people entering the workforce lack skill and experience in the correct use of the more deferential honorific levels.

All of the manners courses had sections on polite language use. The time spent on this topic ranged from thirty minutes to two hours, with approximately half of the time devoted specifically to honorifics. This typically included a discussion of the three main types of honorific verb forms (sonkeigo, subject honorifics or 'respect' forms; kenjyoogo nonsubject honorifics or 'humble' forms; and teineigo addressee honorifics or 'polite' forms) ${ }^{2}$ as well as exercises in which they were given the regular form of a verb such as 'eat' (taberu) and asked to supply the respect form (meshiagaru) and humble form (itadaku). Following this, they were drilled on the correct forms by the instructor or asked to drill each other in pairs. In some courses, the drills were followed by conversation practice in which students were instructed to speak to each other using humble forms for themselves and respect forms for the addressee. This section of the course also included considerable attention to warning students about common mistakes in honorific usage. For instance, one student was critiqued

2 These are grammatical categories traditionally used by Japanese linguists and taught in the education system. 
for saying ossharareta, adding the respect morpheme -are to the verb ossharu which is itself already the respect form of 'to say.' Students were also warned against confusing respect forms and humble forms or mixing them together in the same predicate (e.g., itadaite kudasai 'please eat' which combines the humble form of 'eat' with the respect form for 'please,' or orareru which combines the humble verb oru 'to be' with the respect morpheme-are).

Instructor critiques of the students' linguistic self-presentation frequently involved asking them to gureedo appu ('up-grade') their use of particular stylistic variants to more formal or deferential forms. For example, there are several ways to express the verb 'to do' in Japanese, with yaru typically seen as the most informal and suru being somewhat more formal. ${ }^{3}$ There are also honorific variants: nasaru as the respect form and itasu as the humble form. Students who used yaru to describe their own actions were told to use suru or itasu instead. Similarly, Japanese has several variants of first-person pronouns, with watakushi typically understood as the most polite and deferential. Students who used forms such as atashi or jibun for self-reference were told to use watakushi instead. One student who used jibun was told that this made him sound like he was still a student.

\subsection{Yasashii: Kindness and consideration}

Honorific use was not the only type of polite language covered in the manners training. Students were also instructed in a variety of verbal strategies for creating a yasashii inshoo 'impression of kindness.' These included phrasing requests as questions or apologizing before performing a face-threatening act. One such strategy involves the use of what the instructors called kusshon kotoba 'cushion words,' namely the use of an apology phrase to precede and 'cushion' requests or refusals. For example, in practicing telephone dialogues, students were instructed to use apology phrases such as mooshiwake gozaimasen 'There is no excuse' or osore irimasu 'I'm sorry' (literally 'I'm fearful') before asking someone for their name or informing them that the person to whom they

3 Recent work has emphasized that the indexical meaning of honorific forms is not fixed, but rather emergent in context, with their interpretation dependent on surrounding linguistic and contextual features (see, e.g., papers in Jones \& Ono (2008) as well as the present volume). Despite this variation, Pizziconi (2011) argues that native speakers rely on default interpretations which may be modified or overridden by specific contextual features in actual discourse. It is this type of acontextual default interpretation that I describe here. The type of linguistic correction described here is itself one of the linguistic practices which reinforce such typifications. 
wished to speak was currently unavailable. Similarly, students were instructed to phrase requests as questions, using forms such as itadakemasu ka, literally, 'Can I (humbly) receive the favor of ... .' Explicit instruction in this type of phrasing suggests that Japanese concepts of 'politeness' incorporate not only the appropriate indexing of social position through honorific use, but also the types of verbal strategies for face-threat mitigation described in Brown \& Levinson's (1987) politeness framework (Dunn 2011).

One important component of speaking kindly and considerately involves speaking in ways that are wakari yasui 'easy to understand':

Ano akaruku aite ni hakkiri kikoeru yoo ni, soshite kokoro yasashiku wakariyasuku, soshite, kore ga ma risoo desu ne. Utsukushiku teinei ni iereba desu ne. Dakedo kore ga ichiban de wa nai. Akaruku yasashiku no hoo ga, watakushi wa ano nandomo mooshiagemasu yoo ni daiji to omoimasu. Donna ni kotobazukai ga keigo ga kanpeki de atte mo, kikoenakattara, ne? Donna ni keigo kirei de atte mo, ïmawashi ga kitsukattara doo deshoo to kangaetara wakarimasu yo ne. Dakara, yasashiku ano omoiyari o motte, aite ni tsumari ee jibun ga wakatteiru kedo, aite wa wakaranai deshoo to omou toko kara sutaato shite. Wakariyasuku yasashiku yutte ageru. Soshite kikoeru koto ga jooken desu yo. Moo kikoenakute, haa? tte aite ga omou dake de fushinsetsu. Shigotochuu wa ne.

[Um speaking cheerfully so that the addressee can clearly hear you, and speaking with a kind heart, in ways that are easy to understand, this is the ideal. One can speak beautifully and politely, but that is not the number one issue. As I've said again and again, speaking cheerfully and kindly is more important. No matter how perfect your honorific use, if they can't hear you ... . No matter how beautiful your honorifics, what good is it if your phrasing is harsh? If you think of it that way, you'll understand. So speak kindly, with consideration, and start with the idea that even if you understand what you mean, the addressee may not. Say things in ways that are kind and easy to understand. It's essential that they be able to hear you. If they can't hear you and have to think 'huh?,' that alone is unkind, in the workplace environment.]

In this instructor's analysis, speaking clearly and simply is also speaking kindly because it shows consideration towards the listener. One recurring critique of some students was that they spoke too quietly. One instructor explained that this is not simply a matter of the impression you make as an individual. You are representing your company, and it is important to speak clearly such that the other person does not have to put effort into hearing or understanding what you are trying to say.

Another component of speaking clearly is appropriate vocabulary choice. For example, one young woman in her self-introduction talked about her hobby, Ultimate Frisbee. In critiquing this student, the instructor pointed out that the term 'Ultimate Frisbee' is unfamiliar to most Japanese and that no one had any idea what she was talking about. For this reason, students were instructed to avoid slang, professional jargon, and the overuse of Sino-Japanese compounds 
which can easily be confused with homonyms in spoken Japanese. ${ }^{4}$ For example, during one of the telephone dialogues, one man used the phrase Sanji sugi ni kisha yotei degozaimasu '[He] plans to return to the office after three o'clock.' The instructor suggested replacing the Sino-Japanese compound kisha (帰社) with the verb modoru which would create an aite ga wakari yasui, sofuto na inshoo ('soft, easy to understand impression').

Speaking 'kindly' was distinguished in the training from speaking politely in the sense of using honorific language. In the excerpt quoted above, note how concepts such as kindness (yasashiku) and consideration (omoiyari) are placed in constrast with polite or beautiful language use (utsukushiku tenei ni iereba; keigo kirei de atte). One important concept related to being yasashii is omoiyari 'consideration' or 'empathy' which is also a focus of politeness training in Japanese homes (Clancy 1986) and preschools (Burdelski \& Mitsuhashi 2010). Students in the manners classes were instructed to consider things from the other person's perspective (aite no tachiba ni tatte, kangae) and to put the other person's feelings first (aite no kimochi o saki ni suru). Speaking kindly was not only a matter of memorizing appropriate 'cushion phrases,' but of actively anticipating customers' wants. One instructor gave the example of the shop where she does her dry-cleaning. The store closes at 8 p.m., and she often has trouble getting there in time after work. After seeing her rushing to beat the closing time, the owner told her he is usually there until 8:30, so it would be okay for her to pick up her dry cleaning even after the official closing time. The instructor gave this as an example of how superior customer service involves not simply meeting, but exceeding, the customer's expectations. In this way, concepts such as 'kindness' and 'consideration' are connected to 'Customer Satisfaction' and the presentation of a positive corporate image.

\subsection{Kirei: Politeness as 'beauty'}

In addition to speaking respectfully and considerately, the manners training was also about speaking 'beautifully' in order to convey the appropriate demeanor as a representative of one's company. Phrases such as kanji no yoi 'pleasant' and kirei 'beautiful' were frequently used to describe the type of

4 In contrast with native Japanese forms, Sino-Japanese compounds are typically perceived as more formal, technical and academic (Shibatani 1990: 142-147). Shibatani suggests that the avoidance of these terms in stereotypical women's speech may create an 'impression of softness' (Shibatani 1990: 374). 
movement and vocal expression that the students should target. ${ }^{5}$ Thus, a bow which was correctly executed in terms of form and timing (straight back, bowing at the correct angle, stopping at the bottom and coming up slowly) was described as kirei na ojigi 'a beautiful bow.' Posture, gesture, placement of hands and feet, and the movements used in extending one's business card were also frequently described as kirei. The term kirei was also used to talk about various qualities of a person's speech. For example, the appropriate nasalization of $\mathrm{ga}$ in second-onset syllables was described as making speech sound kirei (e.g., shoonakkoo rather than shoogakkoo for 'elementary school'). ${ }^{6}$ Instructors also emphasized avoiding the use of contractions with glottal stops (e.g., docchi for dochira 'which one,' yappari for yahari 'after all') as well as other types of contractions such as jya for de wa.

Appropriate use of honorific language also makes one's speech kirei. Thus the correction of personal pronouns was described as making one's speech beautiful:

(Referring to worksheet prompts):

Hai sanban. Watashi, atashi, jibun. Kore wa moo jibun no koto wa watakushi to osshatte mite kudasai. Sore dake de kotoba ga kirei desu.

[Number three. Watashi, atashi, jibun. [All typically less formal forms of first-person reference.] Here also please try to say watakushi to refer to yourself. That alone will make your words kirei.]

Similarly, when working on the honorific worksheets, students who correctly replaced a non-honorific verb such as kimasu 'come' with a humble form such as ukagaimasu or mairimasu were praised for using kirei na kotoba 'beautiful words.'

The instructors also emphasized the avoidance of certain phrasings deemed incorrect or hypercorrect. Students were told to avoid ryuukoogo 'slang' or 'trendy words and phrases.' This was justified as making one's speech 'easy to understand,' but a closer analysis suggests that difficulties in comprehension were not the underlying concern. One particular culprit was the widespread tendency to use ni narimasu (literally 'becomes') as an honorific form of the copula as in the phrase:

5 The most frequently occurring adjective or adverb forms in the data were akarui 'bright, cheerful' kirei or utsukushii 'beautiful,' wakari yasui 'easy to understand,' teinei 'polite,' yasashii 'kind,' and kanji no yoi 'pleasant.' There were a total of 26 references to speech style as kirei or utsukushii and 21 references to movement.

6 Word-internal velar nasals are a characteristic feature of the Tokyo standard dialect whose use has declined over the past century (Hibiya 1995; Tanaka \& Yoshida 1997). 
Omatase itashimashita. Hanbaagu ni narimasu.

'Thank you for waiting. Here is your hamburger.' (Literally: Here becomes your hamburger.)

Manners instructors critiqued this usage as incorrect, arguing that use of $n i$ narimasu should be limited to situations in which one thing is actually changing into another. Part-time workers at restaurants and convenience stores were inevitably cited as exemplars of this type of incorrect usage. Some instructors used the terms Kombini keigo or Famirikon keigo 'convenience store honorifics' as a way of characterizing this usage of ni narimasu. These terms were also used for certain uses of $\sim$ no hoo which instructors said should only be used to indicate direction or alternative choices. The combination of multiple honorific morphemes in a single verb (e.g., the previous example of ossharareru for 'to say') was also labeled as 'convenience store honorifics.' Uses which are clearly intended as polite were thus critiqued as grammatically incorrect and as betraying the speaker's lack of cultural knowledge and refinement. The trainees, many of whom would have had precisely this type of part-time job while in college, were encouraged to purge such hypercorrect forms from their speech in order to present a sophisticated corporate image.

\section{Discussion: Deference, demeanor, and global corporate etiquette}

This study confirms previous findings that Japanese understandings of teinei behavior include concepts such as kindness and consideration towards others in addition to displays of deference and respect, primarily through the use of the honorific system. Business manners training also emphasizes a third theme, namely that speech and other aspects of self-presentation be 'beautiful.' Drawing on dictionary definitions, Haugh (2004) argues that the 'polished presentation of self' is part of conceptualizations of politeness in English, but not in Japanese. Yet Pizziconi (2007) suggests that the contrast between displaying affective concern for others versus a focus on the speaker's own demeanor is an important semantic dimension of politeness in both languages. Her analysis recalls Goffman's (1956) distinction between deference, which symbolically expresses the individual's relationship to others, and demeanor, which involves display of the individual's own qualities. In practice, politeness behavior frequently serves both functions simultaneously. For example, honorific use may function not only to express deference to alter, but also to display the speaker's 
own gendered or social class identity as a refined speaker (Hendry 1992; Ide 2006).

The data examined here demonstrate that concern with demeanor is very much a part of manners training in corporate settings. The training focuses on creating a polished self-presentation across a variety of semiotic modalities including dress, movement, vocal expression, and word choice. The use of polite language for demeanor purposes is most clearly apparent in the instructors' concern to eliminate various forms seen as unrefined or hypercorrect. In this discourse, correctness, politeness, and beauty become ideologically fused.

Such connections of deference and demeanor, correctness and politeness, are not unusual in class-stratified societies. Watts (1999) describes how correctness and politeness were conflated in $18^{\text {th }}$ century Britain in the context of new shifts in social mobility, thus allowing a defined standard of polite behavior to serve functions of boundary maintenance in distinguishing the gentry from the rising middle classes. In Tokugawa Japan (1603-1868), the popularity of artistic study and commercially published etiquette manuals allowed well-off commoners to gain cultural capital through emulating the manners and mores of the samurai class despite restrictions on social mobility (Ikegami 2005). The establishment of politeness norms takes on a new function in post-industrial, serviceoriented economies. In a context in which the quality of service becomes more essential to corporate success than the quality of goods per se, corporations have a vested interest in regimenting the emotional display of their service workers (Hochschild 1983; Ashforth \& Humphrey 1993). Companies increasingly seek to control employees' language use and to train employees in appropriate modes of interaction and self-display (Cameron 2000). In this process, communicative skills and performances themselves become a commodity (Urciuoli 2008; Heller 2010).

Japanese manners training must be contextualized within this global trend. Not only is corporate training in linguistic style and interaction increasingly widespread, but there are also some striking similarities in the content of such training and the modalities on which it focuses. Many of the topics covered in the Japanese business manners training are also targets of standardization in British call centers, including 'prosody and voice quality, the way in which particular speech acts should be performed, the choice of address terms/salutations and the consistent use of certain politeness formulae' (Cameron 2000: 324). Similarly, Cohen (2010) describes 'etiquette and image' training for Russian secretaries which involves detailed attention to dress, voice, and movement in ways very reminiscent of Japanese manners training. It is difficult to know to what extent such similarities are the result of globally circulating corporate discourses or whether they are a type of independent invention in which com- 
panies respond in similar ways to similar pressures of providing satisfactory customer service in a highly competitive business environment.

At the same time, Japanese manners training also draws on indigenous cultural roots in its pedagogical concepts. The fusion of ethics and aesthetics can be seen in traditional art forms such as tea ceremony, flower arranging, calligraphy, and the martial arts which are viewed simultaneously as art forms and as 'paths' to spiritual enlightenment (Ikegami 2005). The manners training shares with these traditional art forms a pedagogical emphasis on mastery of standardized forms (DeCoker 1998). It is this focus on mastery of correct form which unites deference and demeanor in the corporate manners training. One must not only bow in order to show respect to the customer, but bow at the correct angle, for the correct number of seconds, with the correct placement of hands and feet. The bow simultaneously displays both deference and a highly polished presentation of self, both of which contribute to the company's public image.

\section{Conclusions}

Corporate manners classes reproduce wider Japanese understandings of politeness as encompassing both deference and kindness. In the manners training, these two aspects of politeness were treated as contrasting, although not contradictory, concepts. This is consistent with previous findings that concepts such as keii 'respect,' reigi 'etiquette,' and teinei 'polite' tend to cluster somewhat separately from shinsetsu 'kind,' and omoiyari ‘consideration' (Pizziconi 2007), and that shitashige 'friendly' actually has a slight negative correlation with teinei (Ide et al. 1992). In contrast to some previous studies (Obana \& Tomoda 1994; Haugh 2004; Pizziconi 2007), the present study did not find a strong emphasis on modesty or reserve (enryo, hikaeme) in the manners training classes. Manners classes did, however, emphasize a third dimension, namely the importance placed on speaking, moving, and dressing 'beautifully.' This demeanor aspect of politeness was generally not identified in previous work on Japanese concepts of politeness, although Pizziconi (2007) found that Japanese do associate teinei 'polite' with joohin 'refined.'

The emphasis on demeanor aspects of politeness found in the business manners training highlights the importance of recognizing the situated nature of metapragmatic discourse. Previous studies of Japanese politeness concepts have relied on dictionary definitions or elicited metapragmatic judgments. By focusing on naturally-occurring metapragmatic discourse, the present study demonstrates that definitions of politeness are not only culturally, but also con- 
textually, specific. In business manners training, politeness is not an end, but a means towards the larger goal of training employees in forms of behavior which will project a desirable corporate image. Deference politeness and demeanor politeness come together to project an image of service which is simultaneously deferential and refined. This is combined with an emphasis on helpfulness and considerateness in which employees are encouraged to take the customers' perspectives and anticipate their needs. All three aspects of politeness (deference, consideration, and demeanor) are thus oriented and connected within the framework of 'Customer Satisfaction.' These politeness behaviors are simplified, formalized, and rationalized such that they can be efficiently taught to new employees from a wide variety of companies. This rationalization of politeness behaviors in the context of customer service in turn connects a specifically Japanese concept of politeness to global trends towards the commodification of language. At the same time, business manners training both draws on and contributes to the national circulation of ideologies of politeness in Japan.

\section{Acknowledgment}

This research was conducted with the support of a Professional Development Assignment from the University of Northern Iowa which allowed me to spend the spring of 2008 as a visiting foreign research scholar at the University of Tsukuba. I would like to thank Risako Ide for serving as my sponsor at the University of Tsukuba, Chihiro Ogura for assistance with transcription, and Shigeko Miyajima for facilitating access to one of the training companies. I am grateful to instructors and other employees of the following companies for their gracious cooperation with my research: Do Creation, Green Sun, JAL Academy, Link and Motivation, PanNations, Temp Staff. I am grateful to Miki Iida, Matthew Burdelski, Barbara Pizziconi, and an anonymous reviewer for helpful comments on an earlier draft of this paper.

\section{Bionote}

Cynthia Dickel Dunn is an associate professor of anthropology at the University of Northern Iowa. Her research interests include Japanese speech styles and honorific use, language ideologies, the commodification of language, and the Japanese sense of self. 


\section{References}

Ashforth, Blake E. \& Ronald H. Humphrey. 1993. Emotional labor in service roles: The influence of identity. Academy of Management Review 18(1). 88-115.

Brown, Keith (ed.). 2006. Encyclopedia of language and linguistics, $2^{\text {nd }}$ ed., Volume 9. Oxford: Elsevier.

Brown, Penelope \& Stephen C. Levinson. [1978] 1987. Politeness: Some universals in language usage. Cambridge: Cambridge University Press.

Burdelski, Matthew \& Koji Mitsuhashi. 2010. 'She thinks you're kawaii': Socializing affect, gender, and relationships in a Japanese preschool. Language in Society 39(1). 65-93.

Cameron, Deborah. 1998. 'Is there any ketchup, Vera?': Gender, power and pragmatics. Discourse \& Society 9(4). 437-455.

Cameron, Deborah. 2000. Styling the worker: Gender and the commodification of language in the globalized service economy. Journal of Sociolinguistics 4(3). 323-347.

Charmaz, Kathy. 2001. Grounded theory. In Robert M. Emerson (ed.), Contemporary field research: Perspectives and formulations, $2^{\text {nd }}$ ed., 335-352. Prospect Heights IL: Waveland.

Clancy, Patricia M. 1986. The acquisition of communicative style in Japanese. In Bambi B. Schieffelin \& Elinor Ochs (eds.), Language socialization across cultures, 213-250. Cambridge: Cambridge University Press.

Cohen, Susanne. 2010. Communicating change in a transforming state: Globalization and the politics of office communication in urban Russia. Ann Arbor, MI: Unpublished Ph.D. dissertation, University of Michigan.

DeCoker, Gary. 1998. Seven characteristics of a traditional Japanese approach to learning. In John Singleton (ed.), Learning in likely places: Varieties of apprenticeship in Japan, 4567. New York: Cambridge University Press.

Dunn, Cynthia Dickel. 1999. Toward the study of communicative development as a life-span process. Anthropology \& Education Quarterly 30(4). 451-454.

Dunn, Cynthia Dickel. 2011. Formal forms or verbal strategies? Politeness theory and Japanese business etiquette training. Journal of Pragmatics 43(15). 3643-3654.

Eelen, Gino. 2001. A critique of politeness theories. Manchester: St. Jerome.

Emerson, Robert M. (ed.). 2001. Contemporary field research: Perspectives and formulations, $2^{\text {nd }}$ ed. Prospect Heights IL: Waveland.

Garrett, Paul B. \& Patricia Baquedano-Lopez. 2002. Language socialization: Reproduction and continuity, transformation and change. Annual Review of Anthropology 31. 339-361.

Goffman, Erving. 1956. The nature of deference and demeanor. American Anthropologist 58(3). 473-502.

Hall, Kira \& Mary Bucholtz (eds.). 1995. Gender articulated: Language and the socially constructed self. New York: Routledge.

Haugh, Michael. 2004. Revisiting the conceptualisation of politeness in English and Japanese. Multilingua 23(1/2). 85-109.

Heller, Monica. 2010. The commodification of language. Annual Review of Anthropology 39. 101-114.

Hendry, Joy. 1992. Honorifics as dialect: The expression and manipulation of boundaries in Japanese. Multilingua 11(4). 341-354.

Hibiya, Junko. 1995. The velar nasal in Tokyo Japanese: A case of diffusion from above. Language Variation and Change 7(2). 139-152. 
Hochschild, Arlie R. 1983. The managed heart: Commercialization of human feeling.

Berkeley: University of California Press.

Ide, Sachiko. 2006. Wakimae no goyōron ['The pragmatics of wakimae']. Tokyo: Taishukan.

Ide, Sachiko, Beverly Hill, Yukiko M. Carnes, Tsunao Ogino, \& Akiko Kawasaki. 1992. The concept of politeness: An empirical study of American English and Japanese. In Richard J. Watts, Sachiko Ide, \& Konrad Ehlich (eds.), Politeness in language: Studies in its history, theory and practice, 281-297. New York: Mouton de Gruyter.

Ikegami, Eiko. 2005. Bonds of civility: Aesthetic networks and the political origins of Japanese culture. New York: Cambridge University Press.

Inoue, Miyako. 2006. Vicarious language: Gender and linguistic modernity in Japan. Berkeley: University of California Press.

Irvine, Judith T. 1989. When talk isn't cheap: Language and political economy. American Ethnologist 16(2). 248-267.

Jones, Kimberly \& Tsuyoshi Ono (eds.). 2008. Style shifting in Japanese. Philadelphia: John Benjamins.

Kokugo Shingikai (Japan National Language Council). 2000. Gendai ni okeru keii hyoogen ['Expressions of respect in the modern age']. Government white paper. Tokyo: Bunkacho.

Lewins, Ann \& Christina Silver. 2007. Using software in qualitative research: A step-by-step guide. Los Angeles: Sage.

Locher, Miriam A. \& Richard J. Watts. 2005. Politeness theory and relational work. Journal of Politeness Research 1(1). 9-33.

Mills, Sara. 2003. Gender and politeness. New York: Cambridge University Press.

Mills, Sara \& Dániel Z. Kádár (eds.). 2011. Politeness in East Asia: Theory and practice. New York: Cambridge University Press

Obana, Yasuko \& Takako Tomoda. 1994. The sociological significance of 'politeness' in English and Japanese languages. Report from a pilot study. Japanese Studies Bulletin 14(2). 37-49.

Okamoto, Shigeko. 1995. 'Tasteless' Japanese: Less 'feminine’ speech among young Japanese women. In Kira Hall \& Mary Bucholtz (eds.), Gender articulated: Language and the socially constructed self, 297-325. New York: Routledge.

Okamoto, Shigeko. 1999. Situated politeness: Coordinating honorific and non-honorific expressions in Japanese conversations. Pragmatics 9(1). 51-47.

Omohundro, John T. 2008. Thinking like an anthropologist: A practical introduction to cultural anthropology. Boston: McGraw-Hill.

Pizziconi, Barbara. 2006. Politeness. In Keith Brown (ed.), Encyclopedia of language and linguistics, $2^{\text {nd }}$ ed., Volume 9, 679-684. Oxford: Elsevier.

Pizziconi, Barbara. 2007. The lexical mapping of politeness in British English and Japanese. Journal of Politeness Research 3(2). 207-241.

Pizziconi, Barbara. 2011. Japanese honorifics: The cultural specificity of a universal mechanism. In Sara Mills \& Dániel Z. Kádár (eds.), Politeness in East Asia: Theory and practice, 45-70. New York: Cambridge University Press.

Schieffelin, Bambi B. \& Elinor Ochs. 1986a. Language socialization. Annual Review of Anthropology 15. 163-191.

Schieffelin, Bambi B. \& Elinor Ochs (eds.). 1986b. Language socialization across cultures. Cambridge: Cambridge University Press. 
Shibamoto Smith, Janet S., \& Debra J. Occhi. 2009. The green leaves of love: Japanese romantic heroines, authenic femininity, and dialect. Journal of Sociolinguistics 13(4). 524-546.

Shibatani, Masayoshi. 1990. The languages of Japan. Cambridge: Cambridge University Press.

Singleton, John (ed.). 1998. Learning in likely places: Varieties of apprenticeship in Japan. New York: Cambridge University Press.

Tanaka, Yukari \& Kenji Yoshida. 1997. Hen'i shooshitsu no katei to sono seiyaku: Yamanishiken seibukan jakunensoo ni okeru 'ga' kooshion. ['Process of variant loss and its constraints: A case of Japanese velar nasal among young people in Yamanishi Prefecture']. Keiryo Kokugogaku (Mathematical Linguistics) 20(8). 368-383.

Urciuoli, Bonnie. 2008. Skills and selves in the new workplace. American Ethnologist 35(2). 211-228.

Watts, Richard J. 1999. Language and politeness in early eighteenth century Britain. Pragmatics 9(1). 5-20.

Watts, Richard J., Sachiko Ide, \& Konrad Ehlich (eds.). 1992a. Politeness in language: Studies in its history, theory and practice. New York: Mouton de Gruyter.

Watts, Richard J., Sachiko Ide, \& Konrad Ehlich. 1992b. Introduction. In Richard J. Watts, Sachiko Ide \& Konrad Ehlich (eds.), Politeness in language: Studies in its history, theory and practice., 1-17. New York: Mouton de Gruyter.

Wetzel, Patricia J. 2004. Keigo in modern Japan: Polite language from Meiji to the present. Honolulu: University of Hawaii Press.

Woolard, Kathryn A. 1998. Introduction: Language ideology as a field of inquiry. In Bambi B. Schieffelin, Kathryn A. Woolard, \& Paul V. Kroskrity (eds.), Language ideologies: Practice and theory, 3-47. New York: Oxford University Press. 
Copyright of Multilingua is the property of De Gruyter and its content may not be copied or emailed to multiple sites or posted to a listserv without the copyright holder's express written permission. However, users may print, download, or email articles for individual use. 